\title{
Accruals, Earnings Quality and Research Methodology
}

\author{
B. Brian Lee \\ Prairie View A\&M University \\ Alfreda Dobiyanski \\ Prairie View A\&M University \\ Marianna Sviland \\ Prairie View A\&M University \\ Limin "Pricilla" Zhu \\ Prairie View A\&M University
}

\begin{abstract}
We first review prior earnings management studies with an emphasis on discretionary accruals as a proxy for earnings management. Discretionary accruals are estimated using widely accepted models, such as the Jones model or its updated ones with additional control variables to improve their prediction power. Nonetheless, estimated discretionary accruals are still subject to model specification errors. Then, we review alternative methods to identify earnings management by evaluating earnings distribution properties and frequencies of digits in collected accounting numbers. These alternative methods can identify anomalies in earnings distributions or frequencies of digits but cannot explain how such anomalies take place. Accordingly, future studies of earnings management may employ these alternative methods in conjunction with discretionary accruals to offer a better insight into earnings management practices.
\end{abstract}

Keywords: discretionary accruals, earnings quality, discontinuities in earnings distributions, frequencies of digits in accounting numbers

\section{INTRODUCTION}

This paper reviews accounting literature associated with noise and informativeness resulting from accruals in earnings with critical comments and discusses research ideas in future studies. A firm's financial performance can be assessed based on two measurement systems: accrual-based or cash-based accounting systems. As indicated in Statement of Financial Accounting Concepts (SFAC) No. 8 (Financial Accounting Standards Board, FASB, 2010), financial statements are prepared to ensure useful information about a firm's financial performance for investors and let them make their informed investment decisions. Cash inflows or outflows do not necessarily represent changes in a firm's economic value, as cash flows are not tightly correlated to the firm's activities in generating or consuming economic 
resources. For example, a firm could receive cash before rendering services or pay for services received to vendors later. Accordingly, Generally Accepted Accounting Principles (GAAP) require public corporations to prepare their financial statements using the accrual-basis accounting system. Following GAAP rules, managers can exercise discretion in reporting revenues or expenses by referring to economic consequences based on key measurement guidelines, such as revenue recognition and matching principles. These accrual accounting rules allow recognition of revenues or expenses at times or under conditions not matched by contemporaneous associated cash flows. That flexibility allows managers to choose a range of events or time periods without violating GAAP or other accounting or regulatory rules.

Thus, discretionary powers can be used in two distinct ways. On one hand, managers have the most detailed knowledge of their firm's financial status and could use that personal knowledge to exercise in a manner that promotes objective disclosure that increases earnings quality and assists investors in making enhanced investment decisions. On the other hand, this information asymmetry and the misaligned interests between managers and shareholders allow managers to exercise their discretion in a manner that promotes their personal agendas (e.g., increased market price, exceeding performance goals, etc.) instead of revealing true underlying economic values. As a result, the existence of discretionary accruals induces noise in the communication of firms' financial conditions. Since managers' actual decision processes are unobservable, some empirical means must be found to determine if managers use their discretion in earnings measurement to enhance the informativeness of earnings or add noise to earnings.

Prior studies have heavily relied on discretionary accruals as a proxy for earnings measurement. The effect of discretionary accruals on earnings quality is controversial. For example, earnings smoothing via discretionary accruals improves the informativeness of earnings (Hunt, Moyer, and Shevlin 2000; Tucker and Zarowin 2006) but, on the other hand, managers may exercise their discretion to manage earnings to meet goal-measured compensation incentives (Warfield, Wild and Wild 1995; Teoh, Welch and Wong 1998a and 998b).

Estimation models based on discretionary accruals are subject to specification errors and thus the power of these models has been questioned. Also, the relevance of discretionary accruals can be tested under the assumption of market efficiency. Accordingly, alternative methods of examining earnings management have been proposed, such as discontinuities in earnings distributions and unusual frequencies of digits in collected accounting numbers to assess noise introduced into earnings. Furthermore, Amiram, Bozanic and Rouen (2015) and Malenko and Grundfest (2014) develop simple proxies, such as Financial Statement Divergence Scores (FSD-scores) and Quadrophobia Scores (Q-scores) for accounting information quality, respectively. Future studies may adopt these alternative methods to document earnings management in conjunction with discretionary accruals.

In the next section, we discuss theoretical models about the improvement of the earnings informativeness through accruals. The following two sections contain empirical findings of earnings management studies based on accruals and distributions of earnings and digits in collected accounting numbers. The final section summarizes the paper's findings.

\section{CONCEPTUAL STUDIES ABOUT THE EFFECTIVE COMMUNICATION OF MANAGERS WITH SHAREHOLDERS}

Healy and Palepu (1993) characterize the information environment of the capital market as: (1) managers know more about a firm's current and future status than do investors, (2) managers do not necessarily make all business decisions to benefit shareholders, and (3) the current accounting systems are far from perfect. This imposes on managers a need to convince shareholders of their firms' outstanding performance and continue their investments, which can be communicated through published financial statements. Healy and Palepu (1993) suggest that managers can also use voluntary disclosure of financing, payout, and financing policies as additional communication tools to investors. For example, a declaration of a cash payout, such as new or an increase in dividends or a stock repurchase may tell shareholders that the firm is doing so well that it has a surplus of cash flows. 
Stocken and Verrecchia (2004) theoretically extend the need for voluntary disclosure suggested by Healy and Palepu (1993) by identifying two distinguishing functions in the financial accounting reporting system: financial reporting system choice and disclosure management. As an example of the financial reporting system choice, a firm can choose an appropriate revenue recognition principle from a set of alternative methods, such as the percentage-of-completion, installment, or cost-recovery method. If a firm chooses an accounting method that properly records its business transactions and maintains a precisely controlled financial reporting system, accounting earnings will closely represent the firm's underlying economic income and value. Under such a precise financial reporting system, managers would have minimal leeway to insert their private information into the process of measuring and reporting earnings and would face additional costs and risks in attempting to do so. Managers attempting to insert private information would also face a much greater risk of being caught and punished by shareholders and other stakeholders. As a result, managers (with and without nefarious intent) would prefer an imperfect financial reporting system with a high degree of flexibility in accounting measurements. With that, managers would have room to employ their private or non-financial information in more realistically measuring earnings. Stocken and Verrecchia (2004) assert that the reduced efficiency in the imperfect financial reporting system would be offset by gains managers would achieve by releasing private information, thereby lowering information asymmetry, and encouraging investors to provide more capital to the firm.

Chaney and Lewis (1995) discuss the release of managers' private information via earnings smoothing in a two-period world where only two types of firms exist: high- and low-value firms. If earnings management takes place within GAAP, reported earnings (before depreciation) must equal cash flow from operations over the life of a firm. Managers of low-value firms have no incentive to overstate earnings, which would result in additional tax liabilities. Rather they would like to defer tax liabilities to future periods. On the other hand, managers of high-value firms expect large cash flows in the future and have confidence in expecting an increase in future earnings. They can communicate their confidence by revealing their positive private information to investors through smoothing earnings upward. Such earnings management would result in an increase in a firm's tax liabilities. As managers of high-value firms expect an increase in their compensation that is based on firm value, additional current tax payments would be outweighed by managers' personal gains from future increases in earnings. Since the earnings smoothing process winnows down noise in earnings, discretionary accruals become more informative.

On the other hand, Trueman and Titman (1988) theorize that earnings smoothing would add more noise in earnings because it is motivated by managers' opportunism. Suppose that managers may try to gain more favorable trade terms from external stakeholders by lowering the possibility of bankruptcy through earnings smoothing. Since such opportunistic earnings smoothing is accomplished by eliminating unfavorable but value-relevant items, noise in earnings increases.

As indicated in Healy and Palepu (1993), information asymmetry exists in the capital market between investors and managers because current financial statements are far from perfect. They do not, according to Healy and Palepu (1993), properly include all the information to assess a firm's current and future economic performance, particularly in nonfinancial areas such as human resources, innovation, customer relationships, and the like. To lessen that imbalance, managers can use accruals as tools to share their private information about a firm's future economic perspective. Earnings thus serves as a relevant and comprehensive proxy for a firm's future cash flows. For example, Bowen, Burgstahler, and Daley (1987) report the incremental information content of earnings beyond cash flow from operations. However, accruals are a double-edged sword with their nature and extent depending upon how managers use them. Accruals used to support managers' opportunism can add noise to earnings and reduce the informativeness of earnings. Because the intent behind managers' behavior cannot be observed, we need to retroactively interpret their behavior by empirically examining the impact of accruals on the earnings series. 


\section{EMPIRICAL FINDINGS BASED ON ACCRUALS}

\section{Informativeness of Accruals}

As financial statements do not directly include accruals, prior studies estimate accruals based on differences between cash flow from operations and earnings (Subramanyam 1996; Sloan 1996; Xie 2001). Cash flow from operations is available from the statement of cash flows while earnings is defined as income before extraordinary items. Cash flow from operations is less subject to managers' influence than is earnings because cash flow from operations results from objectively identifiable transactions including cash inflows or outflows. Bernstein (1993) cautions firms with a high level of earnings and relatively low cash flow from operations that they may be suspected of aggressively increasing earnings via accruals. Following up on this line of thought, Sloan (1996) examines the persistence of the two earnings components-accruals and cash flow from operations-and reports the low persistence of accruals compared to cash flow from operations. Nevertheless, investors appear to fixate on earnings without taking into consideration a difference in persistence between accruals and cash flow from operations. As a result, Sloan (1996) reports a negative association between the relative portion of accruals in earnings and future abnormal stock returns. In other words, overstated stock prices resulting from the high portion of accruals in earnings become adjusted in the future as the reversal of accruals takes place down the road. Since, however, managers cannot manipulate all components in accruals, the findings of Sloan (1996) provide limited insight into the role of accruals in earnings. For example, accruals that are tied with other accounts and computed based on fixed formulae, such as depreciation expenses, cannot be easily manipulated without drawing attention from security analysts and investors.

Subramanyam (1996) partitions accruals into nondiscretionary and discretionary accruals, using the Jones (1991) model. The Jones model assumes that accruals vary with a firm's economic activities and depreciable assets. Nondiscretionary accruals are estimated by regressing changes in revenues and gross balances of property, plant and equipment on accruals. Residuals from the regression model represent discretionary accruals. As a result, discretionary accruals could represent the amount of managers' discretion in measuring earnings. Subramanyam (1996) reports a positive association of discretionary accruals with contemporaneous stock prices and future profitability, such as earnings. The positive association may support a conclusion that managers use accruals to improve the informativeness of earnings by including their private information about a firm's future financial perspective. Subramanyam (1996), however, does not examine whether investors properly value discretionary accruals in determining a firm's value because the persistence of discretionary accruals would be lower than that of other earnings components, such as nondiscretionary accruals and cash flow from operations.

Xie (2001) extends studies of Sloan (1996) and Subramanyam (1996) by examining how investors value discretionary accruals. Xie (2001) reports that discretionary accruals are the least persistent while cash flow from operations is the most persistent over time. As investors fixate on earnings, both discretionary and nondiscretionary accruals are overvalued but cash flow from operations is undervalued. Investors demonstrate more errors in valuing discretionary accruals than nondiscretionary accruals and cash flow from operations. Consequently, firms with upward earnings management through discretionary accruals are associated with negative future stock returns, whereas firms with downward earnings management are associated with positive future stock returns.

A few studies attempt to evaluate directly whether discretionary accruals induce noise in earnings or enhance the informativeness of earnings (Hunt, Moyer, and Shevlin 2000; Tucker and Zarowin 2006). Hunt et al. (2000) empirically examine whether discretionary accruals can improve the informativeness of earnings or add noise in earnings by measuring their multipliers. Hunt et al. (2000) regress the market value of equity on current earnings while controlling for volatilities of key variables, such as cash flow from operations, discretionary accruals, and nondiscretionary accruals. They find a higher multiplier of earnings when earnings volatility becomes lowered through discretionary accruals management. Also, Hunt et al. (2000) report a higher earnings multiplier through smoothing discretionary accruals than nondiscretionary accruals. Thus, they conclude that earnings smoothing using discretionary accruals enhances the informativeness of earnings.

Journal of Applied Business and Economics Vol. 22(1) 2020 
Tucker and Zarowin (2006) examine whether earnings smoothing adds noise to earnings or improve the informativeness of the earnings series with improved research methods. For example, Tucker and Zarowin (2006) measure income smoothing as a negative correlation between a change in discretionary accruals and a change in earnings before discretionary accruals. A strong negative correlation provides evidence of earnings smoothing since an increase in earnings changes is associated with an increase in changes of discretionary accruals. Also, Tucker and Zarowin (2006) introduce a future earnings response coefficient (FERC) to examine an association between current-year stock returns and future earnings at the different levels of earnings smoothing. A FERC is designed to measure how investors could impound expected future earnings in a firm's current value in the efficient capital market. Since stock prices represent a firm's current and future financial performance, a FERC could assess the portion of future earnings shocks that are not a part of current earnings, but already impounded in the current stock price. Therefore, the higher FERC of firms with greater earnings smoothing serves as evidence that earnings smoothing improves earnings informativeness. Their empirical results support that firms with greater smoothing show a higher FERC, consistent with the informativeness of earnings smoothing.

Francis, LaFond, Olsson and Schipper (2005) evaluate the informativeness of earnings by measuring the effect of accruals quality on the cost of capital. The accruals quality is measured by regressing working capital accruals on a time-series of cash flow from operations. The standard deviation of each firm's residuals from the regression model serves as a proxy for accrual quality. In other words, the larger the standard deviation, the poorer the accrual quality. Francis et al. (2005) document that firms with lowquality accruals experience high borrowing costs, low earnings multipliers and high equity betas. Furthermore, when accrual quality is partitioned into innate and discretionary components, low earnings multipliers are primarily associated with the innate component of accruals quality. Therefore, investors are concerned about risks arising from a firm's business model and operating environment, not about managers' influence over earnings measurements in the course of determining firm value.

Courteau, Kao, and Tian (2015) revisit the superiority of the accrual-based system over the cashbased system, using earnings-based (Residual Income Model, RIM) and non-earnings-based (Discounted Cash Flow, DCF) valuation models by hypothesizing that managed accruals lower the informativeness of accruals. The RIM estimates a firm's intrinsic value as a function of book value and residual income, aggregated over forecasted years while the DCF computes a firm's intrinsic value as a function of current net financial assets and a sum of expected cash flows, expected investments, expected return on the previous year's financial assets and residual free cash flows to common stock over forecasted years. Courteau et al. (2015) partition sample firms into two groups: normal and suspect firms. Suspect firms are identified based on criteria suggested by Givoly, Hayn and Yoder (2008). For example, suspect firms report positive discretionary accruals that are greater than reported earnings. Courteau et al. (2015) confirm findings of prior studies that the RIM yields more accurate estimates of a firm's intrinsic value than does the DCF when serious accrual management is not suspected. In the presence of accrual management, however, the superiority of the RIM over the DCF to estimate a firm's intrinsic value has substantially declined.

The overall findings of prior studies show that accruals provide investors with incremental information about a firm's future cash flows beyond current cash flow from operations and support the adoption of the accrual-based accounting system in GAAP (Bowen et al. 1987; Dechow 1994; Liu, Nissim, and Thomas 2002; Dechow, Kothari and Watts 1998). In a general setting of investigation, managers appear to communicate a signal about a firm's future perspective to investors by smoothing earnings via discretionary accruals. Thus, both nondiscretionary and discretionary accruals make an incremental contribution to the informativeness of earnings beyond cash flow from operations. As the expected value of accruals should be zero over the life of a firm, the reversal of accruals, particularly discretional accruals, tends to compromise the quality of earnings persistence. In other words, discretionary accruals display a reduced mapping capacity into future cash flows. Since investors fixate on reported earnings, profitable investment strategies can be constructed by using a negative correlation between the magnitude of discretionary accruals and future stock returns. 


\section{Earnings Management Through Discretionary Accruals}

Healy and Wahlen (1999) describe earnings management as managers' discretion over financial reports to distort a firm's true economic performance and obtain favorable outcomes of contracts that are based on accounting numbers in financial statements. Since earnings management takes place in a clandestine way, it is not easy for investors to identify the effect of earnings management on earnings. On the other hand, if investors are able to undo the effect of earnings management, then there is no reason for managers to engage in earnings management. As a result, prior studies of earnings management design their investigation by identifying incentives and measurement methods to affect earnings, such as abnormal accruals or favorable choices of accounting methods.

Warfield et al. (1995) examine the effect of managerial ownership on earnings management. The separation of ownership and control requires contractual agreements to ensure that managers work on behalf of shareholders. Since such contracts are enforced by referring to accounting numbers employed, managers would be motivated to influence accruals and choose accounting procedures that would generate a favorable impact on these numbers. Warfield et al. (1995) find an inverse association between the magnitude of discretionary accruals and the level of managerial ownership. In other words, managers with low ownership aggressively adjust accounting numbers that would favorably affect the outcome of their employment contracts. Since most outside shareholders do not have access to a firm's internal operations, they rely on financial statements to evaluate managers' financial performance. Thus, managers of a firm with low managerial ownership have high incentives to manage earnings for favorable outcomes. Furthermore, the large magnitude of discretionary accruals is attributed to the reduced informativeness of earnings for firms with low managerial ownership.

Dechow, Sloan and Sweeney (1996) examine the practice of earnings management by firms that are under Securities and Exchange Commission (SEC) investigations for violations of GAAP. These firms created favorable financial status prior to seasoned equity offerings by engaging in aggressive accounting measurement tactics, including (1) an increase in income-increasing accounting procedures, (2) high accruals, and (3) high discretionary accruals. One of the major goals for managers is to reduce the cost of external financing. If firms are identified as manipulators, they face negative consequences in the capital market, such as higher bid-ask spreads, a lower number of security analysts following, higher short-term rates, and higher dispersions of analysts' earnings forecasts. Firms that successfully managed earnings reduced their costs of capital; firms identified as earnings manipulators substantially increased their costs of capital.

Teoh et al. (1998a and 1998b) report positive discretionary accruals before initial public offerings and seasoned equity offerings, respectively. Such positive discretionary accruals lead to overpriced equity values of these firms. As the effect of earnings management reverses in subsequent years, investors become disappointed and adjust firm value downward. For example, firms that employed aggressive accrual strategies before issuing new shares experience lower market performance than do their counterparts by, on average, 15 to 30 percent over the following three years.

These studies identify incentives for managers to influence accounting-based contracts for favorable outcomes or raise external funds at reduced costs using discretionary accruals. These incentives may lead to managers' opportunism with respect to discretionary accruals. Such opportunism is a rational response of managers to capital market expectations, as managers do not want to disappoint investors. For example, Chan, Chan, Jegadeesh and Lakonishok (2006) confirm market anomalies with respect to accruals by reporting a negative association between accruals and future stock returns. They interpret these anomalies as earnings management resulting from investors' extrapolative biases about future growth. Managers are continuously under pressure to meet the market expectation. Few firms can provide positive and growing financial performance without interruption. Managers who do not want to disappoint investors, however, employ creative accounting tactics to delay reporting poor performance until their resources are exhausted. Since investors tend to extrapolate future expectations from past growth, they keep their over-optimistic view of a firm's future performance until the release of bad news. Thus, high accruals eventually lead to low stock returns. 
Since accruals are convenient tools managers use to influence earnings, managers choose short-term gains at the expense of long-term losses, as reported in Chan, Jegadeesh and Sougiannis (2004). Chan et al. (2004) review the reversals of accruals over short-term (up to three years) and long-term (25 years) periods, assuming that all accruals should reverse in future years and sum to zero over a firm's life. They find that upward managed accruals reduce future earnings by $9.6 \%$ over the following three years and $20.2 \%$ in the long-run. Such consistent reversals of accruals in following years serve as an indication of earnings management. Moreover, such reversals become more significant for firms with high priceearnings, market-to-book, and accruals. For example, a subsample of high price-earnings stocks shows $39 \%$ of current accrual reversals in the long-run. In other words, high expected changes in stock prices per one unit of earnings would motivate managers of these firms to engage in earnings management.

\section{Discretionary Accruals as a Proxy for Information Asymmetry}

Easley and O'Hara (2004) develop an asset-pricing model that shows how public and private information affects a firm's returns on assets by focusing on the relationship between a firm's information systems and capital costs. If firms do not supply the sufficient amount of public information to the capital market, thus producing information asymmetry, investors look for increased returns for these firms to compensate for potential losses from trades with better-informed investors who have access to private information sources. Thus, as private information serves as another form of systematic risk, investors want increased returns in equilibrium for bearing the additional risk.

Aboody, Hughes, and Liu (2005) adopt the magnitude of discretionary accruals as a proxy for information asymmetry because discretionary accruals represent managers' influence over earnings measurement. The larger the magnitude of discretionary accruals, the lower earnings quality is. They provide empirical evidence that insiders of firms with high asymmetric information risk as proxied by discretionary accruals earn abnormal profits from trading by taking advantage of their private information. Their empirical findings support the conceptual model of Easley and O'Hara (2004). Dechow and Dichev (2002) report that accrual quality is negatively associated with the magnitude of accruals and a firm's other characteristics, such as the length of the operating cycle and standard deviations of sales, cash flows, accruals, and earnings. As accruals are subject to unintentional errors (e.g., estimation errors) and intentional errors (e.g., accrual management), a large magnitude of accruals in earnings compromises earnings quality by introducing high information noise unrelated to future cash flows. Their empirical results show a negative association between accrual quality and earnings persistence.

Rajgopal and Venkatachalam (2011) examine the effect of earnings quality on an increase in stock return volatility over four decades from 1962 to 2001 as Morck, Yeung and Yu (2000) attribute such increase to the volatility of idiosyncratic stock returns. They adopt two proxies for earnings quality: (1) the mapping capacity of accruals into past and future operating cash flows and (2) the magnitude of discretionary accruals. They conclude that quality is positively associated with the mapping capacity of accruals into cash flows but has an inverse association with the magnitude of discretionary accruals. Rajgopal and Venkatachalam (2011) confirm that a firm's earnings quality is inversely associated with its idiosyncratic return volatility and high return volatility is associated with an increase in the dispersion of analysts' forecasts. This observation can be interpreted as the reduced reliance of security analysts on earnings with low quality in the course of predicting a firm's future earnings. Instead, security analysts would rely on their private information sources to compensate for the perceived low quality of earnings that is publicly available. Accordingly, the dispersion of analysts' forecasts widens as they increase their reliance on private information sources.

The above studies above confirm that discretionary accruals constitute a two-edged sword. On one hand, unsigned discretionary accruals serve as a proxy for information symmetry (Rajgopal and Venkatachalam 2011). As investors are subjected to additional risks for holding stocks with high information symmetry, they expect higher returns from these firms carrying higher risks. On the other hand, discretionary accruals contribute to an increase in an association of earnings with future cash flows (Dechow et al. 1998) as earnings smoothing via discretionary accruals improves the informativeness of 
earnings, that in turn leads to a decrease in information asymmetry (Subramanyam 1996; Hunt et al. 2000; Xie 2001; Tucker and Zarowin 2006).

\section{Meeting Analysts' Expectations Using Discretionary Accruals}

Matsumoto (2002) reports that firms use discretionary accruals to meet or beat the mean of analysts' quarterly earnings forecasts. Firms that meet market expectations show a greater frequency of positive discretionary accruals than do their counterparts that miss them. Similarly, Payne and Robb (2000) report that discretionary accruals depend on the relative amounts of the mean of analysts' forecasts in the month preceding the annual earnings announcement and pre-managed earnings. If the former is higher than the latter, firms report positive discretionary accruals. If, however, the former is lower than the latter, firms report negative discretionary accruals.

Dechow, Richardson and Tuna (2000) also report high discretionary accruals and working capital for firms that meet analysts' forecasts as compared to their counterparts that do not. Besides, these firms show high market capitalization and high market-to-book ratios with positive abnormal stock returns in the following year. As a result, managers of these firms anticipate optimistic financial outcomes in the near future and thus may attempt to exhibit their private information by meeting analysts' forecasts. Otherwise, their shareholders would be unfairly penalized for missing analysts' forecasts.

Burgstahler and Eames (2006) analyze distributions of earnings forecast errors and report a very high frequency of zero and small positive forecast errors and a very low frequency of small negative forecast errors, consistent with the findings of Burgstahler and Dichev (1997). The unusually large number of zero and small positive forecast errors results from the combination of upward earnings management and downward forecast management. In other words, with the end of a year approaching, analysts revise their forecasts downward and managers may engage in managing both cash flows and discretionary accruals upward to meet revised earnings forecasts.

In summary, earnings outperforms cash flow from operations in predicting future cash flows in general research settings. Depending on the underlying motivations of managers, however, accruals would either add noise to reported earnings or improve the informativeness of earnings (Healy and Palepu 1993). To answer this question, accounting researchers compute discretionary accruals as a proxy for earnings management. As accruals depend on business growth and the magnitude of depreciable assets, discretionary accruals are estimated while controlling for these variables, e.g., the Jones model. However, discretionary accruals models are still subject to specification errors (see Bernard and Skinner 1996 for further discussions). In addition, the informativeness of accruals can be tested in the efficient market where investors are assumed to be able to assess the value implications of earnings components. As a result, empirical findings of prior studies about discretionary accruals can be accepted only when discretionary accruals estimated are reliable and the market is efficient. Accordingly, a stream of research has adopted alternative methods to document the practice of earnings management to circumvent the concerns resulting from the estimation of discretionary accruals, such as Burgstahler and Dichev (1997), Carslaw (1988), Amiram et al. (2015), Malenko and Grundfest (2014), and others. Burgstahler and Dichev (1997) report a kinked distribution of earnings numbers as evidence of earnings management. Carslaw (1988) reports the violation of Bendford's Law with respect to the second digit of earnings numbers as the second digit in high magnitude is converted into the first digit. Amiram et al. (2015) and Malenko and Grundfest (2014) propose comprehensive measures of accounting information quality.

\section{EMPIRICAL FINDINGS BASED ON DISTRIBUTIONS OF EARNINGS AND DIGITS IN COLLECTED ACCOUNTING NUMBERS}

\section{Discontinuities in Distributions of Earnings}

Burgstahler and Dichev (1997) report discontinuities in distributions of earnings changes and levels. The frequencies in the area of small earnings decreases and small losses are unusually lower, whereas those in adjacent areas of small earnings increases and small profits are unusually high. As a result, they suspect that small earnings decreases and small losses are managed and transformed into small earnings 
increases and small profits, respectively. For example, they estimate that $8-12 \%$ of firms with small premanaged earnings decreases actually report small earnings increases through earnings management, while $30-44 \%$ of firms with small pre-managed losses report small profits. Their further investigations show that upward earnings management is associated with positive changes in cash flow from operations and working capital. Degeorge, Patel and Zeckhauser (1999) report similar empirical findings that managers try to report profits, sustain recent performance and meet analysts' expectations. Furthermore, they indicate that reporting profits is the most urgent task for managers, while they are less concerned about meeting analysts' expectations.

Dechow, Richardson and Tuna (2003) extend prior studies of discontinuities in earnings distributions by examining how additional resources are obtained to report small profits. Burgstahler and Dichev (1997) report cash flow from operations as the primary source to report small profits. Then, it is not clear whether an increase in cash flow from operations represents either earnings management or exceptional efforts by employees to improve their performance. They find that small profit firms have high discretionary accruals compared to other firms. However, small loss firms also show high discretionary accruals. Accordingly, they could not find convincing evidence of earnings management to explain discontinuities in earnings distributions as both small profit and loss firms show high discretionary accruals. Dechow et al. (2003) offer two explanations for the insignificant evidence of discretionary accruals: (1) earnings is managed to report small profits, but the power of the cross-sectional modified Jones model is too low to estimate the amount of discretionary accruals that are created and (2) small profits result from other business activities rather than earnings management. Dechow et al. (2003) conclude, in contrast to the findings of Degeorge et al. (1999), that managers are more eager to beat analysts' forecasts than the two other benchmarks: avoidance of losses and earnings decreases.

Ayers, Jiang and Yeung (2006) examine whether discretionary accruals are managed upward to beat an earnings benchmark or arise from the growth in a firm's business. Prior studies report that discretionary accruals are positively correlated with earnings (Dechow et al. 1995; Dechow et al. 2003). Accordingly, Ayers et al. (2006) create a series of "pseudo" targets in addition to the actual target in distributions of earnings levels, earnings changes, and earnings surprises. If discretionary accruals are used to beat an actual target, such as small losses or earnings decreases, they expect a positive association of discretionary accruals with beating the actual target. Nonetheless, since there is no incentive for managers to beat pseudo targets, they do not expect a significant number of positive associations between discretionary accruals and beating "pseudo" targets. If a significant number of "pseudo" targets show a positive association with discretionary accruals, then significant discretionary accruals may not represent earnings management, but the existence of their structural association with earnings, i.e., a positive correlation between accruals and earnings. Ayers et al. (2006) find that a significantly large number of pseudo targets are positively associated with discretionary accruals for the benchmarks of positive earnings and earnings increases. Therefore, for the two samples, significant discretionary accruals may not indicate that accruals are managed to meet the thresholds. Nevertheless, Ayers et al. (2006) could not find a significantly large number of pseudo targets in the forecast error distribution that are associated with discretionary accruals and conclude that discretionary accruals may serve as a proxy for earnings management in the case of beating analysts' forecasts.

Burgstahler and Chuck (2014) discuss the findings of prior studies (Dechow et al. 2003; Ayers et al. 2006) that do not support the employment of discretionary accruals to beat the earnings benchmarks in several ways. First, managers could employ a variety of techniques to beat the financial benchmarks, including real business management, accruals management, even fictitious transactions and others. Thus, discretionary accruals alone may not explain earnings management tactics that were employed by managers to beat the earnings benchmarks. Second, discretionary accruals cannot be observed and should be estimated. Accordingly, the estimation models are subject to specification errors. Finally, discretionary accruals employed to beat the earnings benchmarks should be large enough to be detected. For example, Burgstahler and Chuck (2014) illustrate the testing model power, which is .10 when discretionary accruals are on average $80 \%$ of expected earnings. Accordingly, discretionary accruals employed in earnings management should be substantially large to be significant in the testing model. 
In summary, discontinuities in earnings distributions serve as a simple and powerful tool to identify earnings management practices to beat psychological thresholds, such as zero profits, the prior period's earnings or analysts' forecasts. Nonetheless, discretionary accruals alone cannot fully explain beating these thresholds. Several studies propose alternative explanations of discontinuities (Durtschi and Easton 2005 and 2009; Beaver, McNichols and Nelson 2007). Thus, further research is needed to characterize firms that attempt to meet or beat the thresholds by adopting improved research methodologies. Another stream of research in earnings management focuses on digit distributions in collected accounting numbers because digits in collected accounting numbers that are generated in a natural way are expected to converge to the Bendford distributions (Carlaw 1988 and Thomas 1989). Deviations between actual and expected distributions of digits in collected accounting numbers indicate the presence of human intervention in the course of measuring accounting numbers.

\section{Unusual Frequencies of Digits in Collected Accounting Numbers}

Bendford's Law prescribes frequencies associated with digits in a variety of numerical data, including the heights of mountains, the lengths of rivers, transactional accounting numbers, and others that are naturally produced and collected. Each digit in collected numerical data converges to the logarithmic distribution. When certain types of errors are inserted into the data, the distributions of digits that are affected become less smooth and deviate from their expected distributions under Benford's Law. Several studies in accounting use Benford's Law to document earnings management.

Carslaw (1988) finds that New Zealand's firms with positive earnings report an unusually high frequency of 0 but an unusually low frequency of 9 in the second digits of their earnings compared to their Benford distribution. Accordingly, managers of these firms are suspected of engaging in upward earnings management when their pre-managed earnings with a high second digit, 9. Such earnings management raises the first digit of earnings while leaving a 0 as the second digit.

Thomas (1989) investigates U.S. firms with both positive and negative earnings, using the research methodology of Carslaw (1988). Thomas (1989) finds that U.S. firms with positive earnings attempt to improve the first digit of earnings by converting a high second digit as reported by Carslaw (1998). Furthermore, firms with negative earnings show opposite outcomes by retaining an unusually large number of $9 \mathrm{~s}$ but an unusually small number of $0 \mathrm{~s}$. Thus, firms may suppress the first digit of negative earnings by retaining high second digits. Niskanen and Keloharju (2000), Van Caneghem (2002), Skousen, Guan, and Wetzel (2004), and Lacina, Lee, and Kim (2018) find similar types of earnings management based on different country samples, such as Finnish, British, Japanese, and Korean samples, respectively. However, the application of these techniques is limited as a large number of sample firms are required to carry out these research methods.

Amiram et al. (2015) develop FSD-Scores by focusing on the first digit of accounting numbers based on the Benford distribution. Each of the first digits 1 through 9 in accounting numbers is supposed to converge to the logarithmic distribution or Benford's Law. The FSD-Scores are constructed based on cumulative deviations between actual and theoretical frequencies of each leading digit. The FSD-Scores are inversely associated with the quality of an accounting number. Amiram et al. (2015) propose the FSDScores as a simple and convenient research method to measure the quality of accounting numbers because this method does not require estimations, forward-looking information or stock price information. They prove the validity of the FSD-Scores under varying situations where earnings management is suspected, such as restated data, loss firms, firms that beat the zero earnings threshold, and firms with material misstatements that were identified in SEC Accounting and Auditing Enforcement Releases.

In a similar vein, Malenko and Grundfest (2014) develop Q-scores to measure the quality of accounting information for individual firms. The Q-scores represent a firm's strategic rounding of its reported earnings per share (EPS). For example, the EPS of 13.4 cents are rounded down to 13 cents while the EPS of 13.5 cents are rounded up to 14 cents. To address that, managers would be motivated to find an available one- tenth of a cent if their pre-managed EPS happens to be 13.4 cents. This practice would lead to the significant underrepresentation of the number four in the first post-decimal digit of EPS data. Malenko and Grundfest (2014) coin this pattern "quadrophobia" as evidence of earnings 
management. They develop the Q-score for each firm based on the frequency of the number four in the first post-decimal digit of its past EPS data. A firm with a high Q-score represents the low frequency of the number four in the first post-decimal digit of its past EPS data and is suspected of engaging in the practice of earnings management in the future. Malenko and Grunfest (2014) provide empirical evidence that firms with high Q-scores are likely to manage earnings down the road. These firms were required to restate their financial statements, included in SEC Accounting and Auditing Enforcement Releases, and subject to class action securities fraud litigation more often than were their counterparts with low Qscores. Thus, the Q-scores serve as another simple proxy to assess the quality of accounting information.

In summary, Amiram et al. (2015) and Malenko and Grudfest (2014) propose simple research methods to assess the quality of accounting information based on the distributional properties of accounting numbers rather than selected variables that are assumed to be correlated with the quality of accounting numbers. Furthermore, researchers can apply these methods to individual firms or a small sample size as no estimation model is needed. Accordingly, researchers would improve insight into the practice of earnings management using these methods in conjunction with other earnings management measures, such as discretionary accruals.

\section{CONCLUSIONS}

The use of accounting accruals is supposed to improve the informativeness of earnings by reflecting changes in a firm's economic value in accounting numbers on a timely basis. Nonetheless, as managers use their discretion over earnings measurement for their personal agendas, accruals, particularly discretionary accruals could add noise to earnings. Empirical results of prior studies show the incremental informativeness of earnings beyond cash flows in general settings of investigation. However, in the presence of incentives, managers manage discretionary accruals to produce a desired result at the expense of accurate reporting and thus discretionary accruals add noise to earnings. Furthermore, accounting researchers cannot directly observe discretionary accruals and must estimate them using the Jones model or its modified versions by including additional relevant variables to improve the power of their estimating model (see Kothari, Leone, and Wasley 2005). These estimation models, however, are still subject to specification errors. Also, the informativeness of earnings and earnings components is evaluated assuming that the market is efficient, which may not be exactly accurate. Further research is needed to characterize discretionary accruals as a proxy for earnings management.

In addition to discretionary accruals, we review alternative methods of identifying earnings management practices: discontinuities in earnings distributions and unusual frequencies of digits in collected accounting numbers. Discontinuities in earnings distributions represent deviations from the smooth line of earnings distribution and offer possibilities of induced errors to achieve certain thresholds, such as zero profits, the prior period's earnings or analysts' forecasts. However, there is no consensus about whether such discontinuities represent earnings management or the real growth of business through exceptional efforts by employees as discretionary accruals alone cannot fully explain how discontinuities are created. On the other hand, another stream of research evaluates frequencies of each digit in collected accounting numbers, which are supposed to converge to the logarithmic or Bendford distribution. Actual frequencies of digits that deviate from their respective associated Benford frequencies indicate the existence of induced errors in accounting number and require further interpretations about how and why these errors are added. Malenko and Grundfest (2014) and Amiram et al. (2015) extend distributional properties of digits in accounting numbers by developing Q-scores and S-scores to measure the quality of accounting information, respectively. These measures are simple and do not require a large data set to estimate required variables. Accordingly, the employment of these alternative methodologies in conjunction with discretionary accruals would assist researchers in having a better understanding of firms' earnings management practices.

102 Journal of Applied Business and Economics Vol. 22(1) 2020 


\section{REFERENCES}

Aboody, D., Hughes, J., \& Liu, J. (2005). Earnings quality, insider trading and cost of capital. Journal of Accounting Research, 34, 651-673

Amiram, D., Bozanic, Z., \& Rouen, E. (2015). Financial statement errors: evidence from the distributional properties of financial statement numbers. Review of Accounting Studies, 20(4), 1540-1593.

Ayers, B. C., Jiang, J., \& Yeung, P. E. (2006). Discretionary accruals and earnings management: An analysis of pseudo earnings targets. The Accounting Review, 81(3), 617-652.

Beaver, W., McNichols, M., \& Nelson, K. (2007). An alternative interpretation of the discontinuity in earnings distributions. Review of Accounting Studies, 12, 525-556.

Bernard, V.L., \& Skinner, D.J. (1996). What motivates managers' choice of discretionary accruals? Journal of Accounting Economics, 22, 313-325.

Bernstein, L. (1993). Financial Statement Analysis. $5^{\text {th }}$ ed. Homewood, IL: Irwin.

Bowen, R.M., Burgstahler, D., \& Daley, L.A. (1987). The incremental information content of accruals versus cash flows. The Accounting Review, 62, 723-747.

Burgstahler, D., \& Chuck, E. (2014). Detecting earnings management using discontinuity evidence. Working paper, University of Washington, WA

Carslaw, C. (1988). Anomalies in income numbers: Evidence of goal-oriented behavior. The Accounting Review, LXIII (2), 321-327.

Causes and consequences of earnings manipulation: An analysis of firms subject to enforcement actions by the SEC. (1996). Contemporary Accounting Research, 13(1), 1-36.

Chan, K., Chan, L., Jegadeesh, N., \& Lakonishok, J. (2006). Earnings quality and stock returns. The Journal of Business, 7(3), 1041-1082.

Chan, K., Jegadeesh, N., \& Sougiannis, T. (2004). The accrual effect on future earnings. Review of Quantitative Finance and Accounting, 22, 97-12.

Chaney, P. K., \& Lewis, C. M. (1995). Earnings management and firm valuation under asymmetric information. Journal of Corporate Finance, 319-345.

Courteau, L., Kao, J. L., \& Tian, T. (2015). Does accrual management impair the performance of earnings-based valuation models? Journal of Business Finance \& Accounting, 42, 101-137

Dechow, P. M. (1994). Accounting earnings and cash flow as measures of firm performance: The role of accounting accruals. Journal of Accounting \& Economics, 18, 3-42.

Degeorge, F., Patel, J., \& Zeckhauser, R. (1999). Earnings management to exceed thresholds. The Journal of Business, 72(1), 1-33.

Dichev, L. (1997). Earnings management to avoid earnings decreases and losses. Journal of Accounting and Economics, 24, 99-126.

Dichev, I. D. (2002). The quality of accruals and earnings: The role of accrual estimation errors. The Accounting Review, 77(Supplement), 35-59.

Durtschi, C., \& Easton, P. (2005). Earnings management? The shapes of the frequency distributions of earnings metrics are not evidence ipso facto. Journal of Accounting Research, 43, 557-592.

Eames, M. (2006). Management of earnings and analysts' forecasts to achieve zero and small positive earnings surprises. Journal of Business Finance and Accounting, 33(5 \& 6), 633-652.

Earnings management? Erroneous inferences based on earnings frequency distributions. (2009). Journal of Accounting Research, 47, 1249-1281.

Earnings management and the underperformance of seasoned equity offerings. (1998b). Journal of Financial Economics, 50, 63-99.

Easley, D., \& O'Hara, M. (2004). Information and the cost of capital. Journal of Finance, 69, 1553-1583.

Financial Accounting Standards Board. (2010). Statement of Financial Accounting Concepts No. 8. Conceptual Framework for Financial Reporting. Norwalk, CT: FASB.

Francis, J., LaFond, R., Olsson, P., \& Schipper, K. (2005). The market pricing of accruals quality. Journal of Accounting and Economics, 39, 295-327. 
Givoly, D., Hayn, D., \& Yoder, T. (2008). What do analysts rally predict? Inferences from earnings restatements and managed earnings. Working paper, Pennsylvania State University.

Healy, P.M., \& Palepu, K.G. (1993). The effect of firms' financial disclosure strategies on stock prices. Accounting Horizons, 7(1), 1-11.

Hunt, A., Moyer, S.E., \& Shevlin, T. (2000). Earnings volatility, earnings management and equity value. Working paper, University of Washington, WA.

Jones, J. (1991, Autumn). Earnings management during import relief investigations. Journal of Accounting Research, 29, 193-228.

Kothari, P. M., \& Watts, R. L. (1998). The relation between earnings and cash flows. Journal of Accounting \& Economics, 25(2), 133-168.

Kothari, S. P., Leone, A. J., \& Wasley, C. E. (2005). Performance matched discretionary accrual measures. Journal of Accounting and Economics, 39, 163-197.

Lacina, M., Lee, B. B., \& Kim, D. W. (2018). Benford's law and the effects of the Korean financial reforms on cosmetic earnings management. Journal of International Accounting, Auditing and Taxation, 20, 2-17.

Liu, J., Nissim, D., \& Thomas, J. (2002, March). Equity valuation using multiples. Journal of Accounting Research, 40, 135-172.

Malenko, N., \& Grundfest, J. A. (2014). Quadrophobia: strategic rounding of EPS data. Rock Center for Corporate Governance at Stanford University Working Paper No. 65. Retrieved from https://www2.bc.edu/nadya-malenko/Grundfest,Malenko\%20(2014).pdf

Matsumoto, D. (2002). Management's incentives to avoid negative earnings surprises. The Accounting Review, 77(3), 483-514.

Morck, R., Yeung, B., \& Yu, W. (2000). The information content of stock markets: Why do emerging markets have synchronous stock price movements? Journal of Financial Economics, 58, 215-260.

Niskanen, J., \& Keloharju, M. (2000). Earnings cosmetics in a tax-driven accounting environment: Evidence from Finnish public firms. The European Accounting Review, 9, 443-452.

Payne, J., \& Robb, S. (2000, Fall). Earnings management: The effect of ex ante earnings expectations. Journal of Accounting, Auditing, and Finance, 371-92.

Rajgopal, S., \& Venkatachalam, M. V. (2011). Financial reporting quality and idiosyncratic return volatility. Journal of Accounting \& Economics, 51, 1-20.

Richardson, S. A., \& Tuna, A. I. (2000). Are benchmark beaters doing anything wrong. Working paper, University of Michigan, Ann Arbor, MI.

Skousen, C. J., Guan, L., \& Wetzel, T. S. (2004). Anomalies and unusual patterns in reported earnings: Japanese managers round earnings. Journal of International Financial Management and Accounting, 15(3), 212-234.

Sloan, R. G. (1996). Do stock prices fully reflect information in accruals and cash flows about future earnings? The Accounting Review, 71(3), 289-315.

Sloan, R. G., \& Sweeney, A. P. (1995). Detecting earnings management. The Accounting Review, 70(2), 193-225.

Stocken, P. C., \& Verrecchia, R. E. (2004, August-December). Financial reporting system choice and disclosure management. The Accounting Review, 79(4), 1181-1203.

Subramanyam, K. R. (1996). The pricing of discretionary accruals. Journal of Accounting and Economics, 22, 249-281.

Teoh, S. H., Welch, I., \& Wong, T. J. (1998a). Earnings management and the long-run market performance of initial public offerings. Journal of Finance, 53, 1935-1974.

Thomas, J. (1989). Unusual patterns in reported earnings. The Accounting Review, 5(4), 773-787.

Tucker, J. W., \& Zarowin, P.A. (2006). Does income smoothing improve earnings informativeness? The Accounting Review, 81(1), 251-270.

Trueman, B., \& Titman, S. (1988). An explanation for accounting income smoothing. Journal of Accounting Research, 26(Supplement), 127-139.

104 Journal of Applied Business and Economics Vol. 22(1) 2020 
Van Caneghem, T. (2002). Earnings management induced by cognitive reference points. The British Accounting Review, 34/2, 167-178.

Wahlen, J. M. (1999). A review of the earnings management literature and its implications for standard setting. Accounting Horizons, 13(4), 365-383.

Warfield, T. D., Wild, J. J., \& Wild, K. (1995). Managerial ownership, accounting choices, and informativeness of earnings. Journal of Accounting and Economics, 20, 61-91.

Why are earnings kinky? An examination of the earnings management explanation. (2003). Review of Accounting Studies, 8, 355-84.

Xie, H. (2001). The mispricing of abnormal accruals. The Accounting Review, 76(3), 357-373. 